Aim of the study: The purpose of this study was to investigate the presence of vasoactive intestinal polypeptide (VIP), neuropeptide Y (NPY) and calcitonin gene related peptide (CGRP) neuropeptides in neoplastic tissue of the large intestine. The results obtained were compared to an unchanged part of the intestine originating from the same patient.

Material and methods: The tissue samples were taken from the postoperative part of the intestine, resected during an operation due to treatment of colon cancer. Tissues were taken from 15 patients. Concentrations of neuropeptides were determined by ELISA tests, and results were calculated per $1 \mathrm{~g}$ of fresh tissue. The data obtained were statistically analysed.

Results: In tissues of the neoplastic tumour of the sigmoid colon and rectum the concentration of VIP and NPY was determined $(28.9 \mathrm{ng} / \mathrm{g}$ and 8.6 $\mathrm{ng} / \mathrm{g}$, respectively). The observed values were statistically significantly lower than those observed in corresponding tissues of unchanged intestinal segments (83.9 ng/g for VIP and $19.5 \mathrm{ng} / \mathrm{g}$ for NPY). Surprisingly, amounts of CGRP were very similar in both neoplastic and intact tissues (13.3 ng/g and $13.4 \mathrm{ng} / \mathrm{g}$ respectively).

Conclusions: Immunoenzymatic investigations allow one to establish the concentration of neuropeptides associated with the enteric nervous system in can cer tissues of the large intestine. Various concentrations of these neuropeptides were observed in particular patients of both compared groups. The performed statistical analysis did not reveal associations between degree of cancer infiltration within the colonic wall and the level of presence of investigated neuropeptides in either cancer or control tissues. The fact of presence of these neuropeptides in cancer tissues confirmed by this study should be underlined at the same time.

Key words: colon cancer, enteric nervous system, neuropeptides, calcitonin gene related peptide, neuropeptide $\mathrm{Y}$, vasoactive intestinal polypeptide.

\section{Concentration of vasoactive intestinal polypeptide, neuropeptide $Y$ and calcitonin gene related peptide in neoplastic tissue of the human large intestine}

\author{
Janusz Godlewski ${ }^{12}$, Zenon Pidsudko ${ }^{3}$, Waldemar Sienkiewicz ${ }^{3}$
}

1Department of Human Histology and Embryology, Faculty of Medical Sciences, University of Warmia and Mazury in Olsztyn, Poland

2Division of Oncology, Department of Oncological Surgery, Faculty of Medical Sciences, University of Warmia and Mazury in Olsztyn, Poland

${ }^{3}$ Department of Animal Anatomy, Faculty of Veterinary Medicine, University of Warmia and Mazury in Olsztyn

\section{Introduction}

In the neurons of the enteric nervous system (ENS) besides classical neurotransmitters such as acetylcholine and noradrenalin there coexist other biologically active substances, including neuropeptides. In physiological conditions, within nervous structures supplying human large intestines the presence of vasoactive intestinal polypeptide (VIP), calcitonin gene related peptide (CGRP) and neuropeptide Y (NPY) was found [1-5].

Until now there have been no data regarding the presence of neuropeptides in neoplastic tissues of the human and animal large intestines. Studies dealing with neuropeptides in cancer tissues in organs other than the large intestine revealed the presence of these substances within organs studied. It was reported that VIP, CGRP and NPY were found in human non-malignant and malignant tissues of the prostate gland and urinary bladder [6]. Similarly, pituitary adenyl cyclase-activating polypeptide (PACAP) is present in tumour tissues of the ovary, prostate gland and mammary gland [7-9]. In these papers except for confirmation of the presence of PACAP, VIP and NPY, there is no explanation of the possible role of neuropeptides mentioned above in carcinogenesis of these organs. On the other hand, other results lead to conclusions indicating neuropeptides as endogenous factors influencing cancer growth [10]. VIP is presumed to be such a factor influencing the growth of cancer cells of the lung, breast, prostate, colon and urinary bladder [11, 12]. The other studies dealing with the presence of neuropeptides in the cancer process showed significant increase of galanin in cancer tissue as well as in blood in a group of patients with colon cancer. This increase correlated with the degree of cancer invasion and stage of disease and could be considered as a novel colon cancer biomarker [13].

Taking into consideration the lack of data regarding the presence of neuropeptides in neoplastic tissue of the large intestine, we decided to investigate the concentration of VIP, NPY and CGRP in cancer tissues of the colon and rectum. The results obtained were compared to those from unchanged, control segments of the large intestine originating from the same patient.

\section{Material and methods}

The tissues were taken from patients suffering from cancer of the sigmoid colon or rectum who underwent surgery at the Oncological Surgery Department in the Hospital of Warmia and Mazury Oncological Center between 
13.07.2004 and 06.06.2005. Tissues were taken from 15 patients ( 9 females and 6 males). Average age of patients was 63.0; the youngest patient was 41, the oldest 78 years old (Permission of Bioethical Commission of the Regional Medical Board of Warmia and Mazury in Olsztyn No. 107/2004/II dated 01.06.2004).

Tissues were taken during resection of the sigmoid colon or anterior resection of the rectum, from patients who were in relatively good condition, without any other important diseases. Directly after resection of the intestinal segment, two small pieces comprising the entire wall of the intestine were cut out, one from the segment infiltrated by cancer, the second one from the part of the organ which showed no pathological changes, minimum 5-7 centimetres from the infiltrated part. Then, the samples were weighed and kept in liquid nitrogen until further processing. Tissue concentrations of neuropeptides were determined by ELISA tests (Table 1) (Peninsula Laboratories, INC) according to the instructions attached to the kit. Absorbance was measured with the immunoplate reader Dynex MRX (Dynex Technologies) with test filter $450 \mathrm{~nm}$. A 10-point standard curve was prepared, and results were calculated per $1 \mathrm{~g}$ of fresh tissue. The data obtained were statistically analysed.

Table 1. ELISA kits (Peninsula Laboratories Inc.) used in this study

\begin{tabular}{|c|c|c|}
\hline Substance & Cod & Lot \\
\hline VIP & S-1183 (EIAH-7161) & 021071 \\
\hline NPY & S-1220 (EIAH-7172) & 021068 \\
\hline beta-CGRP & S-1200 (EIAH-6012) & 021072 \\
\hline
\end{tabular}

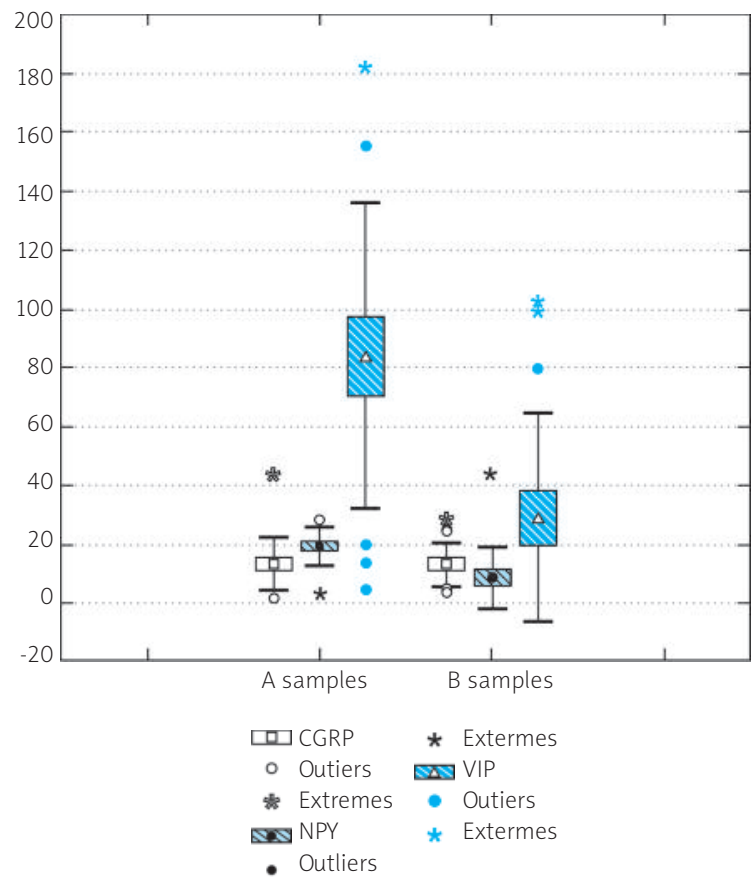

Fig. 1. Diagram showed an average quantity (in ng/g), standard error and standard deviation of each neuropeptide in A and B samples group within the wall of the large intestine

\section{Results}

The data obtained showed a statistically significant decrease in the concentration of VIP in cancer tissues (B samples) as compared to control tissues (A samples) (28.94 $\mathrm{ng} / \mathrm{g}$ and $83.87 \mathrm{ng} / \mathrm{g}$ of fresh tissue respectively). Calculated $p$ level $=0.000058$ did not exceed the assumed level of significance $\alpha=0.05$ (in the nonparametric Mann-Whitney test).

Statistically significant differences in NPY contents were also found between B and A samples. NPY concentration was lower in B samples (average is $8.67 \mathrm{ng} / \mathrm{g}$ ) than that in A samples (average is $19.49 \mathrm{ng} / \mathrm{g}$ ); $p=0.000001$, not exceeding assumed level of significance $\alpha=0.05$.

The results of examinations show similar contents of CGRP in B and A samples (13.33 ng/g and $13.35 \mathrm{ng} / \mathrm{g}$ of fresh tissue respectively). Calculated probability $p=0.604839$ exceeded the level of significance $\alpha=0.05$.

The statistical analysis did not reveal correlations between degree of cancer invasion within the colonic wall and the concentrations of investigated neuropeptides in either cancer or control tissues.

\section{Discussion}

Previous studies have shown the high presence of VIP in the wall of the small and large intestines in humans. Higher content of VIP was observed in the muscular layer in comparison to the mucosal and submucosal membrane. It was also established that VIP-ergic components of the ENS induce relaxation of the muscular membrane of the intestines, increase intestinal secretion and relax the intesti-

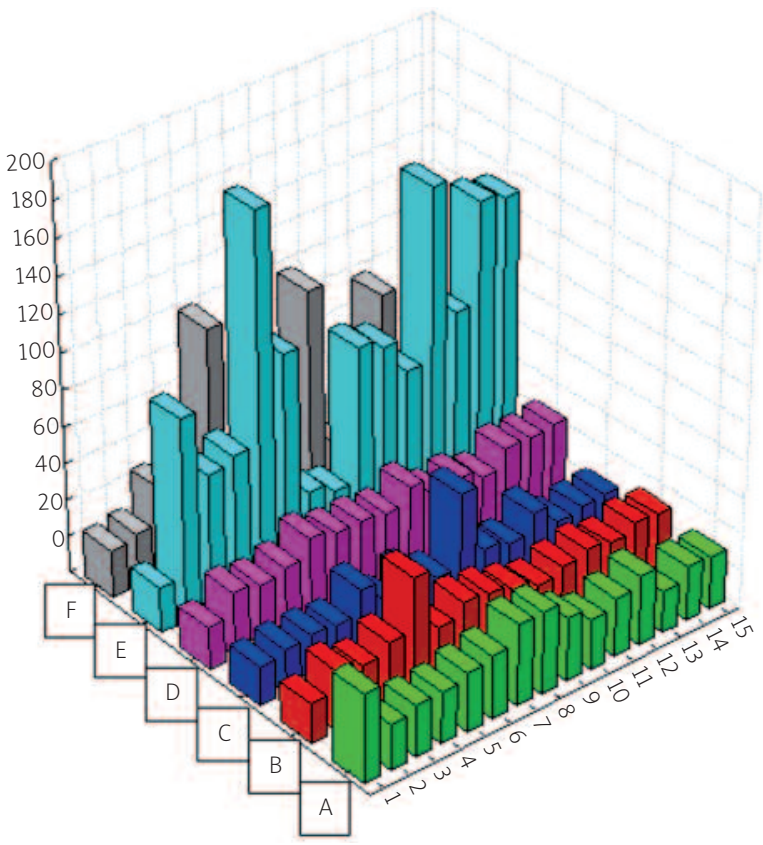

Fig. 2. Differences of neuropeptides concentrations in particular patients in both compared groups. 1-15 numbers of patients; A - CGRP in A samples, B - CGRP in B samples, C - NPY in A samples, D - NPY in B samples, E - VIP in A samples, F - VIP in B samples 
Table 2. Concentration of investigated neuropeptides in large inetestine, results of the ELISA tests, (A - samples taken from part of intestine without pathological changes, B - samples taken from cancer infiltration)

\begin{tabular}{|c|c|c|c|c|}
\hline & $\begin{array}{l}\text { Average quantity } \\
\text { of neuropeptide: } \\
\text { ng/g of fresh tissue }\end{array}$ & $\begin{array}{l}\text { Standard deviation: } \\
\mathrm{ng} / \mathrm{g} \text { of fresh tissue }\end{array}$ & $\begin{array}{l}\text { Minimum quantity } \\
\text { of neuropeptide: } \\
\text { ng/g of fresh tissue }\end{array}$ & $\begin{array}{l}\text { Maximum quantity } \\
\text { of neuropeptide: } \\
\text { ng/g of fresh tissue }\end{array}$ \\
\hline VIP - A samples & 83.87 & 55.51 & 4.35 & 188.07 \\
\hline VIP - B samples & 28.94 & 35.11 & 4.03 & 110.08 \\
\hline NPY - A samples & 19.49 & 6.69 & 2.57 & 30.95 \\
\hline NPY - B samples & 8.67 & 11.60 & 1.19 & 62.69 \\
\hline CGRP - A samples & 13.35 & 9.04 & 0.46 & 46.82 \\
\hline CGRP - B samples & 13.33 & 8.34 & 2.44 & 36.04 \\
\hline
\end{tabular}

nal blood vessels [1, 14-22]. The study reports present the tissue concentration of VIP, NPY and CGRP in the large intestinal wall infiltrated by neoplasm. A statistically significant decrease in the level of VIP in the intestinal wall infiltrated by neoplasm was found as compared to intact tissue. Similar changes were observed in patients with pathological constipation [23-25]. This related result may confirm impaired peristalsis due to colon cancer invasion. The other study showed no changes in VIP tissue concentration in large intestine samples collected from pigs suffering from inflammation provoked by the bacteria Brachyspira hyodysenteriae [26]. Such differences can be explained by the difference between inflammatory and neoplastic processes. In the above case the inflammatory process was acute and included a large part of the intestine or even the whole intestine. It is also possible that the mechanism of reaction of the nervous system in neoplasia is different.

In the human large intestine the presence of NPY was found mostly in the muscular layer, and also a large amount of NPY was found within the sphincters of the gastrointestinal tract of man, which may suggest a role of this neuropeptide in the regulation of the tonus of the musculature of these anatomical structures. It was also found that NPY inhibits the contraction of the intestinal muscular layer $[2,17,19,27,28]$. The present study showed lower concentration of NPY in tissues of the large intestine infiltrated by cancer than in healthy intestinal tissues. In other studies, no changes were observed in the level of NPY within the wall of the large intestines in the course of such diseases as diverticular disease of the large intestines and idiopathic constipation as well as postradial enteropathy [23, 24]. In the experimental studies performed on animals concerning plasticity of innervation of the gut in the acute inflammatory process, it was found that the concentration of NPY in the wall of the large intestine in the pig increased [26].

It could be accepted correlations between decrease of NPY concentrations in cancer tissue with lower density of the NPY-ergic nerve fibres and perikarya observed in previously conducted microscopic examinations. Confirmed changes of NPY presence may suggest disturbed proper colon peristalsis.

CGRP is present in sensory and excretory compartments of the ENS. Additionally, immunoreactivity to CGRP was found in endocrine cells in the human small intestine $[5,19,21]$. In the present study, CGRP was found in tissues of the large intestine obtained from patients suffering from intestinal cancer. The levels of CGRP were similar in both neoplastic and control tissue samples, but it should be stressed that concentration of this neuropeptide differed between the particular samples (decreases and increases were observed). In 8 of 15 studied samples, an increase in CGRP concentration was observed. Such a result can be explained by the presence of CGRP not only in neuronal elements of the intestine but also in endocrine cells of the mucosa, which was previously described in humans by Timmermans [5]. It should also be stressed that solid tumour infiltration constituted a large portion of the sample and the mucosa within the cancer tissues was destroyed. Localization of CGRP in both above-mentioned sites of the intestines undoubtedly hampered the correct interpretation of the results obtained in this study. This interpretation is not helped by the fact that in neoplasm infiltrated tissues of the genitourinary tract (urinary bladder, prostate) other scientists found a significant decrease of CGRP concentration [6]. The surprisingly high level of CGRP determined in the present study (more than half of "pathological" samples) requires further detailed investigations. Other investigations carried out on experimental animals are not very helpful to interpret these results. In experimentally evoked acute inflammation of the large intestine in laboratory animals, at the beginning of the inflammatory process, a decrease in CGRP content in all layers of the intestinal wall was observed, but then a gradual increase in the peptide concentration was observed. It should be underlined that CGRP is inherent in sensory neurons of ENS [29-33].

This study has confirmed the presence of VIP, NPY and CGRP within neoplastic tissues of the human large intestine. It could be assumed that these substances are localized within persistent neuronal elements in cancer infiltration. Unfortunately, this assumption was not confirmed by immunohistochemical investigations, which revealed absence of neuronal elements within solid cancer tissues. However, malformation of the nervous structures in the close vicinity of the cancer infiltration was found [34]. And finally, certainly surprising are the results dealing with CGRP concentrations which were similar in both pathological and control tissue samples. The only possible explanation of this 
finding is that in neuronal elements displaced by cancer infiltration there is a particularly high concentration of this neuropeptide, significantly higher than in the rest of the intestine wall. Considering this fact, higher concentration of CGRP in components of ENS destroyed by cancer could be a focus of further investigation of this neuropeptide as a colon cancer biomarker, similar to galanin mentioned in the introduction.

\section{References}

1. Ferri GL, Adrian TE, Ghatei MA, et al. Tissue localization and relative distribution of regulatory peptides in separated layers from the human bowel. Gastroenterology 1983; 84:777-786.

2. Ferri GL, Adrian TE, Allen JM, et al. Intramural distribution of regulatory peptides in the sigmoid-recto-anal region of the human gut. Gut 1988; 29:762-768.

3. Wattchow DA, Furness JB, Costa M. Distribution and coexistence of peptides in nerve fibers of the external muscle of the human gas trointestinal tract. Gastroenterology 1988; 95:32-41.

4. Crowe R, Kamm MA, Burnstock G, Lennard-Jones JE. Peptide-containing neurons in different regions of the submucous plexus of human sigmoid colon. Gastroenterology 1992; 102:461-467

5. Timmermans JP, Scheuermann DW, Barbiers M, Adriaensen D, Stach W, Van Hee R, De Groodt-Lasseel MH. Calcitonin gene-related peptide-like immunoreactivity in the human small intestine. Acta Anat (Basel) 1992; 143: 48-53.

6. Ohtake R. Four putative neuropeptides concentrations in the human urogenital tract. Comparison of the neuropeptides concentration between malignant and benign tissues. Nippon Naibunpi Gakkai Zasshi 1989; 65: 1105-15.

7. Odum L, Fahrenkrug J. Pituitary adenylate cyclase activating polypeptide (PACAP) in human ovarian cancers. Cancer Lett 1998; 125: 185-9.

8. García-Fernández MO, Solano RM, Carmena MJ, Busto R, Bodega G, Ruíz-Villaespesa A, Prieto JC, Sánchez-Chapado M. Expression and distribution of pituitary adenylate cyclase-activating peptide in human prostate and prostate cancer tissues. Regul Pept 2002; 110: 9-15.

9. García-Fernández MO, Bodega G, Ruíz-Villaespesa A, Cortés J, Prieto JC, Carmena MJ. PACAP expression and distribution in human breast cancer and healthy tissue. Cancer Lett 2004; 205: 189-95.

10. Moody TW, Chan D, Fahrenkrug J, Jensen RT. Neuropeptides as autocrine growth factors in cancer cells. Curr Pharm Des 2003; 9: 495-509.

11. Rozengurt E. Neuropeptides as growth factors for normal and cancerous cells. Trends Endocrinol Metab 2002; 13: 128-34.

12. Le SV, Yamaguchi DJ, McArdle CA, Tachiki K, Pisegna JR, Germano P. PAC1 and PACAP expression, signaling, and effect on the growth of HCT8, human colonic tumor cells. Regul Pept 2002; 109: 115-25.

13. Kim KY, Kee MK, Chong SA, Nam MJ. Galanin is up-regulated in colon adenocarcinoma. Cancer Epidemiol Biomarkers Prev 2007; 16: 2373-8.

14. Ferri GL, Adrian TE, Soimero L, McGregor GP, et al. Regulatory peptide distribution in separated layers of the human jejunum. Digestion 1987; 37: 15-21.

15. Domoto T, Bishop AE, Oki M, Polak JM. An in vitro study of the projections of enteric vasoactive intestinal polypeptide-immunoreactive neurons in the human colon. Gastroenterology 1990; 98: 819-27.

16. Brookes SJ, Steele PA, Costa M. Identification and immunohistochemistry of cholinergic and non-cholinergic circular muscle motor neurons in the guinea-pig small intestine. Neuroscience 1991; 42: 863-78.

17. Surprenant A. Control of the gastrointestinal tract by enteric neurons. Annu Rev Physiol 1994; 56: 117-40.

18. Furness JB, Young HM, Pompolo S, Bornstein JC, Kunze WA, McConalogue K. Plurichemical transmission and chemical coding of neurons in the digestive tract. Gastroenterology 1995; 108: 554-63.

19. Timmermans JP, Adriaensen D, Cornelissen W, Scheuermann DW. Structural organization and neuropeptide distribution in the mammalian enteric nervous system, with special attention to those components involved in mucosal reflexes. Comp Biochem Physiol A Physiol 1997; 118: 331-40.

20. Hens J, Schrodl F, Brehmer A, et al. Mucosal projections of enteric neurons in the porcine small intestine. J Comp Neurol 2000; 421: 429-36.

21. Lomax AE, Furness JB. Neurochemical classification of enteric neurons in the guinea-pig distal colon. Cell Tissue Res 2000; 302: 59-72.

22. Bornstein JC, Costa M, Grider JR. Enteric motor and interneuronal circuits controlling motility. Neurogastroenterol Motil 16 Suppl 2004; 1: 34-8.

23. Koch TR, Carney JA, Go L, Go VL. Idiopathic chronic constipation is associated with decreased colonic vasoactive intestinal peptide. Gastroenterology 1988; 94: 300-10.

24. Milner P, Crowe R, Kamm MA, Lennard-Jones JE, Burnstock G. Vasoactive intestinal polypeptide levels in sigmoid colon in idiopathic constipation and diverticular disease. Gastroenterology 1990; 99: 666-75.

25. Prommegger R, Marksteiner J, Wetscher G, et al. Obstructive ileus of large bowel is associated with low tissue levels of neuropeptides in prestenotic bowel segment. Dig Dis Sci 1997; 42: 1513-8.

26. Łakomy M, Sienkiewicz W, Żmudzki J, Kaleczyc J, Wąsowicz K. Changes in the expression of some neuropeptides in the intestines and nerve ganglia during porcine dysentery. Bull Vet Inst Pulawy 2005; 393-38

27. Koch TR, Roddy DR, Carney JA, Telander RL, Go VL. Distribution, quantitation, and origin of immunoreactive neuropeptide $Y$ in the human gastrointestinal tract. Regul Pept 1988; 21: 309-19.

28. Allen JM, Hughes J, Bloom SR. Presence, distribution, and pharmacological effects of neuropeptide $Y$ in mammalian gastrointestinal tract. Dig Dis Sci 1987; 32: 506-12.

29. Eysselein VE, Reinshagen M, Cominelli F, et al. Calcitonin gene-related peptide and substance $P$ decrease in the rabbit colon during colitis. A time study. Gastroenterology 1991; 101: 1211-1219.

30. Eysselein VE, Reinshagen M, Patel A, Davis W, Nast C, Sternini C. Calcitonin gene-related peptide in inflammatory bowel disease and experimentally induced colitis. Ann N Y Acad Sci 1992; 657:319-327.

31. Miampamba M, Chery-Croze S, Chayvialle JA. Spinal and intestinal levels of substance $P$, calcitonin gene-related peptide and vasoactive intestinal polypeptide following perendoscopic injection of formalin in rat colonic wall. Neuropeptides 1992; 22: 73-80.

32. Miampamba M, Sharkey KA. Distribution of calcitonin gene-related peptide, somatostatin, substance $P$ and vasoactive intestinal polypeptide in experimental colitis in rats. Neurogastroenterol Moti 1998; 10: 315-29.

33. Sharkey KA, Kroese AB. Consequences of intestinal inflammation on the enteric nervous system: neuronal activation induced by inflammatory mediators. Anat Rec 2001; 262: 79-90.

34. Godlewski J. Morphological changes in the enteric nervous system caused by carcinoma of the human large intestine. Folia Histochem Cytobiol 2010; 48: 157-62.

\section{Address for correspondence}

\section{Janusz Godlewski MD, PhD}

Bankowców 35

10-628 Olsztyn

tel. +48698694528

e-mail: janusz350@poczta.onet.pl 